\title{
Androgenic Regulation of Tubulin Gene Expression in Axotomized Hamster Facial Motoneurons
}

\author{
Kathryn J. Jones ${ }^{1}$ and Monica M. Oblinger ${ }^{2}$ \\ 'Departments of Physical Therapy, and Anatomy and Cell Biology, University of Illinois at Chicago, Chicago, Illinois 60612 \\ and ${ }^{2}$ Department of Cell Biology and Anatomy, The Chicago Medical School, North Chicago, Illinois 60064
}

\begin{abstract}
We have previously demonstrated that systemic administration of testosterone increases the rate of axonal regeneration following facial nerve crush in adult male hamsters. In this investigation, the molecular mechanisms by which androgens may enhance axonal regeneration were examined. Specifically, the following question was addressed using Northern blot and in situ hybridization with three cytoskeletal CDNA probes complementary to $\beta_{11}-, \beta_{11}-$, and $\alpha_{1}$-tubulin mRNA: does exogenous testosterone augment axotomy-induced changes in tubulin mRNA expression in hamster facial motoneurons (FMN)? Adult male hamsters were subjected to unilateral facial nerve severance, with the opposite side serving as an internal control. One-half of the animals were subcutaneously Implanted with Silastic capsules containing crystalline testosterone propionate and the other half implanted with blank capsules. Postoperative survival times were 2 and $7 \mathrm{~d}$. At $2 \mathrm{~d}$ after axotomy alone, no changes in levels of any of the three tubulin mRNAs were observed in the injured FMN. However, by $7 \mathrm{~d}$ after axotomy, significant increases in all three tubulin mRNAs were observed. This time course of axotomy-induced changes in tubulin gene expression is consistent with findings in other injured neuronal populations. Administration of testosterone at the time of injury had two major effects on the cytoskeletal response pattern in axotomized FMN. First, testosterone differentially regulated the set of tubulin mRNAs examined, in that $\beta_{11-}$ tubulin mRNA levels were selectively altered by the steroid, whereas $\beta_{\mathrm{III}}$ - or $\alpha_{1}$-tubulin mRNAs were not. Second, administration of testosterone at the time of injury resulted in a more rapid induction of $\beta_{11}$-tubulin mRNA changes in axotomized neurons relative to injury alone. These findings lend support to the hypothesis that testosterone enhances the rate of axonal regeneration through an augmentation in the neuronal cytoskeletal response pattern after axon disconnection.
\end{abstract}

[Key words: testosterone, peripheral nerve regeneration, axotomy, cytoskeleton, androgens, motor neurons]

\footnotetext{
Received May 18, 1993; revised Nov. 10, 1993; accepted Nov. 24, 1993.

This work was supported by NIH Grant NS-28238 (K.J.J.) and NS-21571 (M.M.O.). We thank Drs. Nick Cowan, Steve Farmer, and Anthony Frankfurter for generously providing us with the various tubulin cDNA probes used in this study. The technical expertise of Judith Pickett is also greatly appreciated.

Correspondence should be addressed to Dr. Kathryn J. Jones, Department of CBN and Anatomy, Loyola University School of Medicine, 2160 S. First Avenue, Maywood IL 60153.

Copyright (C) 1994 Society for Neuroscience $0270-6474 / 94 / 143620-08 \$ 05.00 / 0$
}

It is generally thought that steroid hormones act on target tissues primarily through an intracellular receptor-mediated mechanism to alter gene expression in a cell/tissue-specific manner (Yamamoto, 1985). Recent research has focused on the characterization of these intracellular receptors as signal transduction molecules and the elucidation of their functions as nuclear transcriptive factors that regulatc the transcription of a host of steroid-specific genes (Evans, 1988). From neuroendocrine research over the past decade, it appears that gonadal steroids are neurotrophic agents capable of modulating many aspects of neuronal growth involved in the reparative processes following injury (Cohen and Pfaff, 1981; Jones et al., 1985, 1986a,b, 1990; Matsumoto et al., 1988a,b; Goldstein et al., 1990; Gould et al., 1990), a concept we have recently extrapolated to the neuronal regeneration field. Using the well-characterized hamster facial motoneuron as the model system (LaVelle and LaVelle, 1984), we established that the gonadal steroid testosterone accelerates the functional recovery from facial paralysis induced by facial nerve crush in adult male hamsters (Kujawa et al., 1989). Subsequent studies indicate that these effects of the steroid on functional recovery are exerted predominantly at the level of the facial neuron and through a mechanism involving an increase in the rate of regeneration without a shortening in the delay of sprout formation (Kujawa and Jones, 1990; Kujawa et al., 1991).

These effects of testosterone on axonal outgrowth rate parallel those found in the conditioning lesion paradigm, in which a second nerve crush is done several days after a first nerve crush (McQuarrie, 1983; Oblinger and Lasek, 1984; Kujawa et al., $1989,1991)$. Thus, a possible mechanism for the observed effects of gonadal steroids on accelerating the regeneration rates of injured facial motoneurons is that testosterone acts in a neurotrophic manner to prime the neuronal cell body and alter the synthetic capabilities of the regenerating neuron, as has been suggested for the conditioning lesion paradigm. If so, what genes would be predicted to be affected by the hormone? It is now firmly established that the family of cytoskeletal and associated proteins forming the microtubule and intermediate filament systems play key roles in defining axonal shape and conferring stability to maturing axons (Chapin and Bulinski, 1992; Vallee, 1992). Changes in the expression of these gene families have been well documented for a number of neuronal injury models, and their importance in axonal elongation following axotomy has been clearly defined (Hoffman and Cleveland, 1988; Wong and Oblinger, 1990; Tetzlaff et al., 1991). Indeed, alterations in cytoskeletal gene expression have been identified in the conditioning lesion paradigm (McQuarrie, 1983).

The regulation of neurite outgrowth by gonadal steroids in 
both in vivo and in vitro systems has been demonstrated in numerous studies (Toran-Allerand, 1976; Faivre-Baumann et al., 1981; Kurz et al., 1986; Reisert et al., 1987; Matsumoto et al., 1988a,b; Goldstein et al., 1990). A relationship between neurons displaying a rapid increase in stable microtubules and an enhanced rate of neurite outgrowth has been demonstrated in several studies (Cambray-Deakin et al., 1987; Burgoyne and Cambray-Deakin, 1988). Ferreira and Caceres (1991) have provided evidence that the gonadal steroid estrogen stimulates neurite outgrowth in cultured mediobasal hypothalamic neurons through the selective induction of the tau proteins, microtubuleassociated proteins that can increase microtubule stability. Thus, members of the cytoskeletal and associated gene families are likely to be differentially regulated by testosterone after injury, in a manner that may be causally related to the hormonally induced changes in axonal regeneration rates. In this study, we tested that hypothesis using in situ hybridization with several tubulin cDNA probes.

\section{Materials and Methods}

Animals and surgical procedures. Adult male golden hamsters (Harlan Sprague-Dawley, Indianapolis, IN) weighing 100-120 gm were used in all experiments. Animals were anesthetized with Nembutal $(35 \mathrm{mg} / \mathrm{kg}$, i.p.) for all surgical procedures. Using aseptic techniques, the right facial nerve of each animal was exposed at its exit from the skull through the stylomastoid foramen and transected using iridectomy scissors. Immediately after this unilateral nerve transection procedure, a small incision was made along the small of the back and two Silastic capsules $(0.062$ inch i.d. $\times 0.095$ inch o.d., equilibrated in sterile physiological saline) were subcutaneously implanted and secured with sutures (Krey and McGinnis, 1990; Kujawa et al., 1991). This hormone paradigm, which provides high physiological serum levels of the steroid (Krey and McGinnis, 1990), has previously been shown to accelerate the rate of regeneration in adult male hamsters (Kujawa et al., 1991). In one group of animals, the capsules were packed with crystalline testosterone propionate (TP), and in the second group (sham condition), the capsules were empty (Kujawa et al., 1991). At 2 or $7 \mathrm{~d}$ following nerve transection and capsule implant surgery, the animals were deeply anesthetized with ether and decapitated, and their brains were quickly removed.

$c D N A$ probes. The probes used were cDNAs specific for the following tubulin isotypes: $\alpha_{1}$-tubulin [M $\alpha 1$ from Dr. Nick Cowan (Lewis et al., 1985)], class $\beta_{\mathrm{II}}$-tubulin [RBT 1,3'UT, from Dr. Steve Farmer (Bond et al., 1984)], class $\beta_{\mathrm{II}}$-tubulin (KS-5, from Dr. Anthony Frankfurter). For hybridization specific to $\beta_{\mathrm{HII}}$-tubulin mRNA, we used an Apal fragment of the entire KS-5 clone that encodes the terminal lysine and $\sim 750$ base pairs of 3'UT sequence (Jiang and Oblinger, 1992). For blot hybridizations, cDNA inserts were isolated from plasmids and labeled with ${ }^{32} \mathrm{P}-\mathrm{dCTP}$ using the Prime-It kit (Stratagene). For in situ hybridizations, cDNA inserts were labeled with either ${ }^{35} \mathrm{~S}$-dCTP or ${ }^{33} \mathrm{P}$-dATP by nick translation.

$R N A$ isolation and Northern blotting. Freshly dissected brains were blocked with a sterile razor blade and a thin slice from the region of brainstem $(\sim 1 \mathrm{~mm}$ thick) containing the facial motor nucleus (FMN) was taken from each brain. Tissue micropunches that contained the FMN were obtained bilaterally from such slices as described previously (Jones and Evinger, 1991). Total RNA was isolated from the tissue punches as described (Chomczynski and Sacchi, 1987). For each RNA sample, tissue punches from three animals were pooled; in each case the experimental (axotomy side) and contralateral control side FMN were kept separate. For each hormone condition (+TP or sham implant) at the $2 \mathrm{~d}$ and the $7 \mathrm{~d}$ postaxotomy times, three different series of RNA samples were prepared. Each series of RNA samples was used to prepare duplicate blots.

The total RNA concentration of each of the different samples was determined spectrophotometrically and $5 \mu \mathrm{g}$ of total RNA from each of the samples was electrophoresed on $1.2 \%$ agarose gels in the presence of formaldehyde (Ausubel et al., 1987). The RNA was blotted onto Nytran membranes using a Posiblot apparatus (Stratagene), and crosslinked to the membranes by exposure to $0.12 \mathrm{~J}$ of ultraviolet light. Blots were hybridized with ${ }^{32}$ P-labeled cDNA probes using conditions described (Ausubel et al., 1987). Blots were typically washed to a final stringency of $0.1 \times \mathrm{SSC}$ (standard saline citrate) with $0.1 \% \mathrm{SDS}$ at $50^{\circ} \mathrm{C}$. Autoradiographs were made using Kodak X-OMAT-AR film in cassettes containing a single Cronex intensifying screen. Typically, blots were sequentially reprobed with the different tubulin probes after stripping them by immersion in boiling water for $5 \mathrm{~min}$. The sequence in which the blots were probed with the various CDNAs was varied such that a different order was used for each of the blots.

In situ hybridization. For in situ hybridization, brains were obtained from animals in each of the $7 \mathrm{~d}$ postaxotomy conditions (+TP or sham implant). The brainstem blocks were removed and rapidly frozen in powdered dry ice immediately after removal from the animals. Using a cryostat, $10-\mu \mathrm{m}$-thick frozen sections through the FMN were cut and mounted on gelatin chrome-alum-subbed slides. Sections were fixed by immersion in $4 \%$ paraformaldehyde for $90 \mathrm{~min}$ and then hybridized with labeled cDNA probes (see below) as described previously (Jiang and Oblinger, 1992; Oblinger and Pickett, 1992). After hybridization, the sections were washed to a final stringency of $0.1 \times$ SSC with $0.1 \%$ SDS at $50^{\circ} \mathrm{C}$, dehydrated through ethanols, air dried, placed in x-ray film cassettes, and exposed to Kodak EMC \#1 film at $20^{\circ} \mathrm{C}$ for $3-10 \mathrm{~d}$. The slides were subsequently removed from the cassettes, dipped in Kodak NTB2 emulsion (diluted 1:1 with $600 \mathrm{~mm}$ ammonium acetate), incubated in the dark from 5-7 d, and then developed. The sections were stained with cresyl violet and coverslipped prior to light microscopic evaluation.

Densitometry and image analysis. The autoradiograms from the Northern blots were scanned using a laser densitometer (LKB Ultroscan XL). Film autoradiograms from the hybridized histological sections were scanned using a ScanJet IIc (Hewlett Packard) interfaced with a Macintosh IIsi. Using the software program IMAGF. 4.1, optical density values from the region of the FMN (user-defined in each section) were determined. Experimental and control side values were determined from at least 10 different sections and the data were averaged. Quantitative data were statistically evaluated using the Mann-Whitney $U$ test at the $p<0.05$ level where indicated.

\section{Results}

The experiments addressed the question of whether or not exogenous testosterone propionate (TP), given to gonadally intact male hamsters, alters the pattern of tubulin gene expression that is induced by axotomy of neurons in the FMN. Northern blot analysis was initially used to examine the effects of transecting the facial nerve on the levels of three different tubulin mRNAs in the FMN of animals that were either treated with exogenous TP or that received sham implants at the time of nerve injury. Figure 1 illustrates that transection of the facial nerve resulted in a dramatic increase in the levels of $\beta_{\mathrm{II}}, \beta_{\mathrm{III}}$, and $\alpha_{1}$-tubulin mRNAs in the axotomized FMN relative to the contralateral control nucleus. These changes were readily apparent at $7 \mathrm{~d}$ postaxotomy in blots of RNA obtained from FMN tissue punches from both untreated and TP-treated animals (Fig. 1 $A-C$ ). Replicate experiments gave highly similar results.

Administration of exogenous TP at the time of axotomy of FMN had several effects on tubulin gene expression. First, there was an apparent augmentation of $\beta_{\mathrm{II}}$-tubulin mRNA levels in the axotomy-side FMN at $7 \mathrm{~d}$ postaxotomy in the TP-treated group relative to the sham-implanted group (Fig. 1A). This augmentation was limited to the $\beta_{\mathrm{II}}$-tubulin mRNA since the relative change in $\beta_{1 I^{-}}$and $\alpha_{1}$-tubulin mRNA levels in the axotomy-side FMN $7 \mathrm{~d}$ after nerve transection appeared to be similar in both the sham-implanted and TP-treated animals (Fig. 1B,C). The second effect of exogenous TP administration was an acceleration of tubulin mRNA level increases after axotomy. That is, in the TP-treated group of animals, a slight increase in the levels of $\beta_{1 \mathrm{II}}$-tubulin mRNA was observed in the axotomy-side FMN relative to the contralateral control side nucleus by $2 \mathrm{~d}$ after nerve transection (Fig. $1 A$ ). However, in the sham-implant condition, no increase in tubulin mRNA levels was apparent in the axotomy side FMN at $2 \mathrm{~d}$ after axotomy (Fig. $1 A$ ). The 

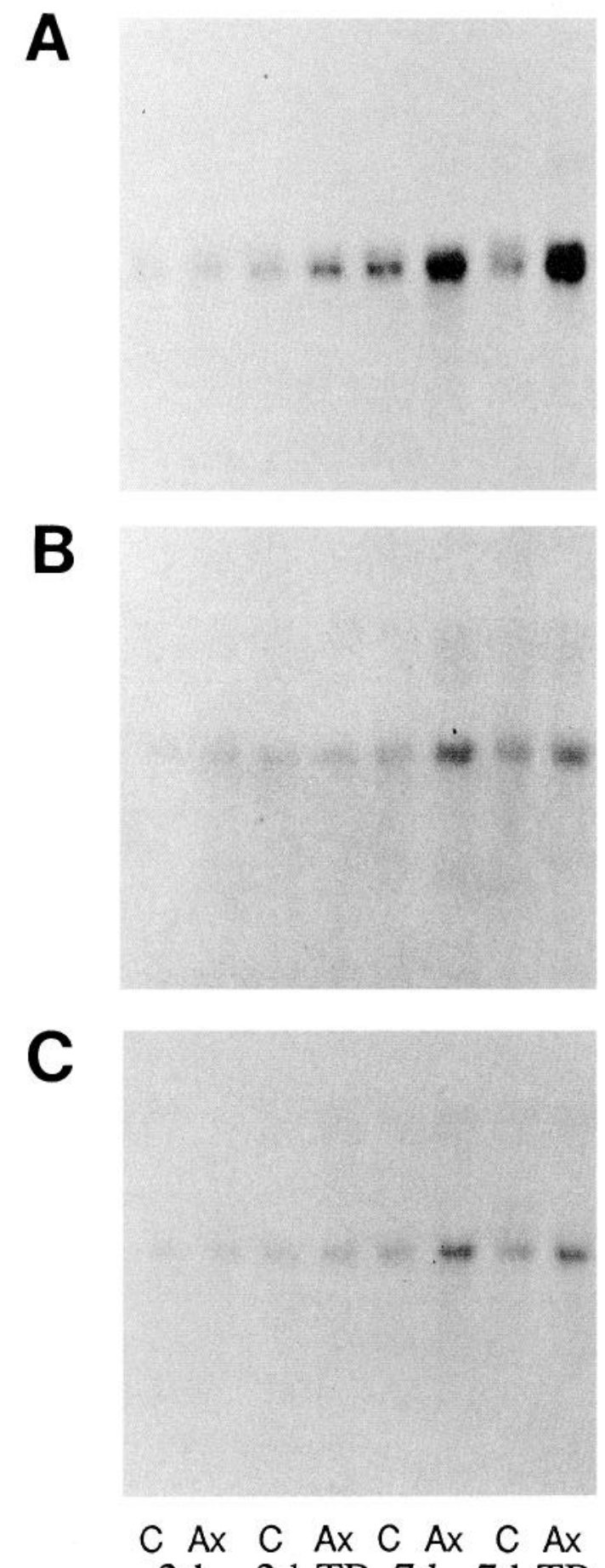
2d 2d-TP 7d 7d-TP

Figure 1. Autoradiograms of Northern blots showing changes in the levels of three different tubulin mRNAs in FMN as a consequence of axotomy and testosterone propionate $(T P)$ administration. The cDNA probes used for hybridizations were specific for the mRNAs of $\beta_{11}$ tubulin $(A), \beta_{\mathrm{III}}$-tubulin $(B)$, and $\alpha_{1}$-tubulin $(C)$. In all cases, equal amounts of total RNA $(5 \mu \mathrm{g})$ isolated from contralateral control $(C)$ or axotomyside $(A x)$ FMN at $2 \mathrm{~d}$ and $7 \mathrm{~d}$ after nerve transection were run on the gels. The postaxotomy times for the non-hormone-treated and for the TP-treatment group samples are indicated below the corresponding gel lanes. effects of TP treatment at $2 \mathrm{~d}$ appeared to be restricted to the $\beta_{\mathrm{II}}$-tubulin mRNA species since no differences in $\beta_{\mathrm{III}}$ - or $\alpha_{1^{-}}$ tubulin mRNA levels were apparent in the axotomy-side FMN relative to the contralateral control at $2 \mathrm{~d}$ posttransection in the TP-treated condition (Fig. $1 B, C$ ). Again, replicate experiments gave highly similar results.

To examine the magnitude of change in tubulin mRNA levels in the FMN as a consequence of axotomy with or without exogenous hormone administration, densitometry of the autoradiograms of the northern blots was done (Fig. 2). Figure 2 shows the averaged densitometric evaluations of the mRNA changes. Quantitative analysis indicated that the $\beta_{\mathrm{II}}$-tubulin mRNA species was the most substantially affected of the three mRNAs examined in this study. By $7 \mathrm{~d}$ postaxotomy in the sham-implanted animals, the level of $\beta_{11}$-tubulin mRNA in the axotomized FMN was increased $130 \%$, relative to the contralateral side (Fig. 2A). In the TP treatment group at $7 \mathrm{~d}$ postaxotomy, the $\beta_{\mathrm{II}}$-tubulin mRNA levels in the axotomized nucleus were increased $157 \%$, relative to the contralateral side (Fig. $2 A$ ). In both the TP-treated group and the sham implant group at $7 \mathrm{~d}$ postaxotomy, the increases in $\beta_{\mathrm{II}}$-tubulin mRNA levels in the axotomized FMN compared with the uninjured contralateral controls were statistically significant. In addition, $\beta_{\mathrm{II}}$-tubulin mRNA levels in the TP-treated, axotomy side FMN at $7 \mathrm{~d}$ were significantly greater than those in the axotomy-side FMN in the sham implant condition at $7 \mathrm{~d}$. At the $2 \mathrm{~d}$ postaxotomy time, the levels of $\beta_{11}$-tubulin mRNA in the axotomized FMN in TPtreated animals were also significantly greater than those in the uninjured contralateral control FMN (135\%). In contrast, no significant differences in $\beta_{\mathrm{II}}$-tubulin mRNA levels were observed in the $2 \mathrm{~d}$ sham implant group.

The magnitude of change in $\beta_{\mathrm{III}}$-tubulin mRNA levels in the axotomized FMN was considerably less than that for $\beta_{\mathrm{II}}$-tubulin mRNA. At $7 \mathrm{~d}$ postaxotomy in the sham implanted animals, a $65 \%$ increase in $\beta_{\mathrm{III}}$-tubulin mRNA levels was observed in the axotomized FMN relative to contralateral control (Fig. $2 B$ ). The magnitude of change was similar to that in the TP-treated animals at $7 \mathrm{~d}$ where the axotomized FMN $\beta_{\mathrm{II}}$-tubulin mRNA levels were increased $62 \%$, relative to the contralateral side (Fig. $2 B$ ). Both of the increases in the axotomy groups relative to control were statistically significant. The levels of $\alpha_{1}$-tubulin mRNA were significantly increased in axotomized FMN relative to contralateral control nuclei at $7 \mathrm{~d}$ in the sham condition ( $86 \%$ increase). In the TP treatment condition, the $72 \%$ increase in $\alpha_{1}$-tubulin mRNA levels in the axotomy-side FMN relative to contralateral control was also significant.

Interestingly, modest increases in tubulin mRNA levels in the uninjured contralateral FMN at $7 \mathrm{~d}$ postaxotomy were consistently found in these experiments. The levels of each of the different tubulin mRNAs assayed were higher in uninjured contralateral control FMN at $7 \mathrm{~d}$ postaxotomy than in control nuclei at $2 \mathrm{~d}$ postaxotomy (Fig. 2). For example, $\beta_{11}$-tubulin mRNA levels in the control side nuclei of TP-treated animals at $7 \mathrm{~d}$ were threefold greater than the levels in the control side FMN of TP-treated animals at $2 \mathrm{~d}$ (Fig. 2A). Increases in tubulin mRNA levels in uninjured contralateral neurons had been previously reported in the FMN (Pearson et al., 1988) as well as in contralateral dorsal root ganglion neurons after unilateral axotomy (Wong and Oblinger, 1990). TP treatment did not have a significant effect on tubulin mRNA levels in uninjured contralateral control FMN. That is, the levels of tubulin mRNAs in the contralateral FMN were not significantly different in TP- 
treated compared to sham-implanted animals at the $7 \mathrm{~d}$ postaxotomy time (Fig. 2).

The expression of $\beta_{\mathrm{II}}$-tubulin mRNA in the FMN was further examined using in situ hybridization and film autoradiography of brainstem sections at $7 \mathrm{~d}$ postaxotomy from TP-treated and sham-implanted animals. Figure 3 shows a representative autoradiogram of a section through the FMN from a TP-treated animal. Qualitative evaluation readily revealed a higher level of labeling over the axotomy-side FMN compared to the contralateral control side nucleus in all preparations from both TPtreated and nontreated animals (Fig. 3A). Quantitation of the film autoradiographic material using densitometry with image analysis software revealed an average increase of 1.75-fold in $\beta_{\mathrm{II}}$-tubulin mRNA levels in the axotomy-side over the contralateral control side in the sham-implanted group (Fig. $3 B$ ). This value is similar to the 2.3-fold increase in $\beta_{11}$-tubulin mRNA levels in the FMN found by Northern blotting (Fig. $2 A$ ). For the TP-treated group, the in situ hybridization results indicated a 2.72 -fold increase in $\beta_{\mathrm{II}}$-tubulin mRNA levels in the axotomy side versus contralateral control side FMN at $7 \mathrm{~d}$ (Fig. $3 B$ ). Again, these values were similar to the 2.6 -fold increase in $\beta_{I^{-}}$tubulin mRNA levels found by Northern blot analysis of the 7 d postaxotomy TP-treated animals (Fig. $2 A$ ).

Finally, emulsion autoradiograms of facial motor neurons after in situ hybridization with a $\beta_{\mathrm{II}}$-tubulin probe were evaluated to examine the effects of exogenous TP administration in conjunction with axotomy at the cellular level. Figure 4 shows examples of contralateral control and axotomized neurons in the FMN at $7 \mathrm{~d}$ postaxotomy in a sham-implanted animal (Fig. $4 A, B$ ) and in a TP-implanted animal (Fig. $4 C, D$ ). At a cellular level, it was readily apparent that axotomized neurons (Fig. $4 B, D)$ had higher levels of labeling than matched contralateral side control neurons (Fig. $4 A, C$ ). There were also indications from qualitative evaluation that the relative change in labeling (axotomy side vs contralateral control side) was greater in the TP-treated animals. Light microscopic evaluation revealed an apparent effect of axotomy on the somal size of neurons in the FMN. Quantitative grain counting of neurons in the FMN was not done in the present study but the issue of cell size changes in relation to specific mRNA content changes in neurons in the FMN as a function of axotomy and hormone treatment will be addressed by a major quantitative in situ hybridization study in the future.

\section{Discussion}

Alterations in levels of mRNAs encoding proteins essential for axonal regrowth after injury have been documented for a number of different neuronal populations (Wong and Oblinger, 1990; Tetzlaffet al., 1991). In accordance with those data, the evidence presented in this study demonstrates that, in adult male hamsters, severance of the facial nerve at the stylomastoid foramen results in an increase in the levels of $\beta_{\mathrm{II}^{-}}, \beta_{\mathrm{III}^{-}}$, and $\alpha_{1}$-tubulin mRNAs in the hamster FMN by the end of the first week. These molecular components of the axon reaction are temporally consistent with previous morphological and autoradiographic studies in this cell type, in which it has been shown that the nucleolar response predominates in the early phases of the axon reaction and the peak of the overall cellular response does not occur until later in the first postoperative week (LaVelle and LaVelle, 1984). Administration of testosterone (TP) at the time of facial nerve injury has two major effects on tubulin gene expression in the injured facial neurons. First, TP differentially regulates the set
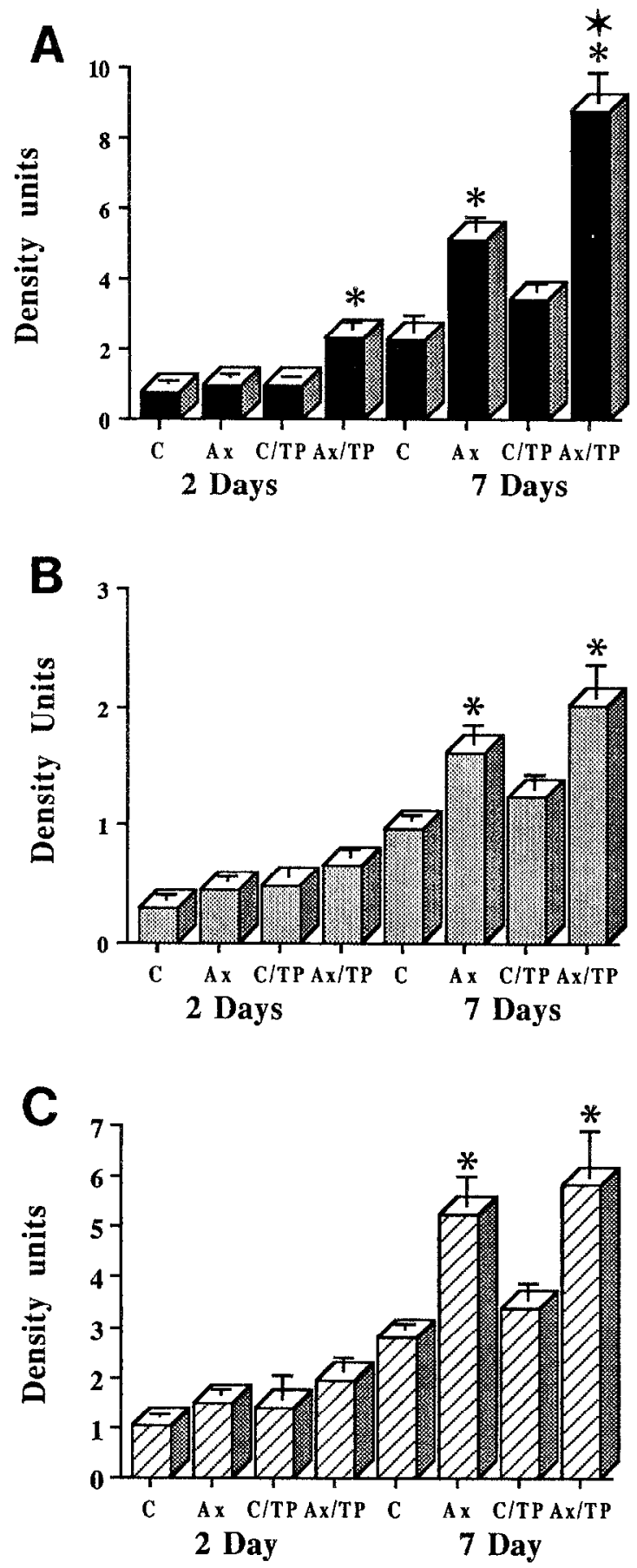

Figure 2. Densitometric analyses of autoradiograms of Northern blots showing changes in tubulin mRNA levels in the FMN as a result of axotomy and hormone treatment. Data shown were obtained from blots probed for $\beta_{\mathrm{II}}$-tubulin $(A), \beta_{\mathrm{III}}$-tubulin $(B)$, and $\alpha_{1}$-tubulin $(C)$ mRNAs. Mean values $( \pm$ SEM) were obtained from autoradiographs of three different Northern blots, each containing different RNA samples from three pooled FMN in each condition. The abscissa markings use $C$ to indicate the contralatcral control side samples in the sham conditions, $A x$ to indicate samples from the axotomy side (no exogenous hormone treatment), $C / T P$ to indicate contralateral control samples in the TPtreated groups, and $A X / T P$ to indicate samples from the axotomy side in the TP-treatment groups. The times after nerve transection are indicated. Asterisks show significant differences between the axotomy and corresponding control groups; the star indicates significant difference between the two axotomy groups at $7 \mathrm{~d}$. 

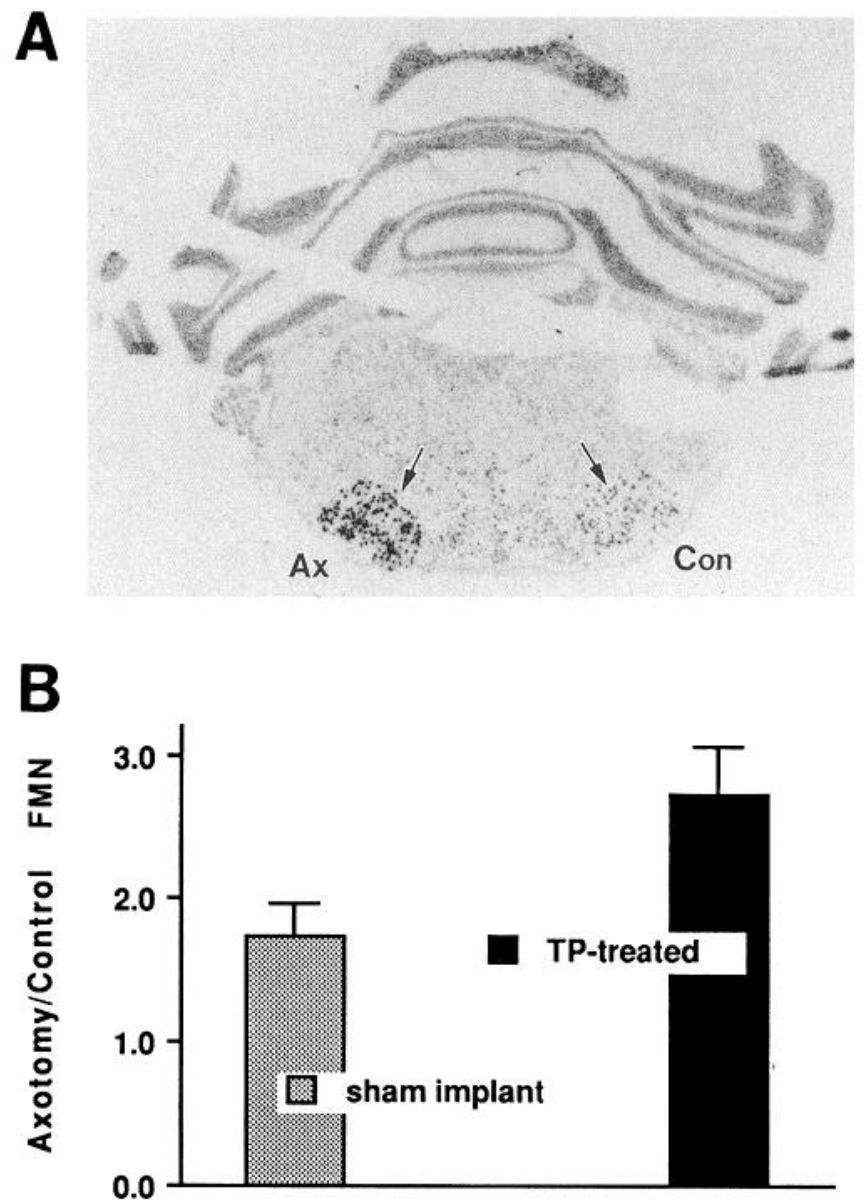

Figure 3. A, Representative film autoradiogram of a brainstem section after in situ hybridization with a $\beta_{11}$-tubulin cDNA probe. The section is through the FMN from a TP-treated animal $7 \mathrm{~d}$ after unilateral facial nerve transection. The axotomy side $(A x)$ and the contralateral control (Con) side FMN are shown (arrows point to the nucleus on each side). $B$, Quantitation of the in situ hybridization film autoradiographic material to assess changes in $\beta_{11}$-tubulin mRNA levels in the FMN as a consequence of axotomy with or without exogenous TP treatment. The data are expressed as mean ratios of labeling (from scanned film autoradiographs) of axotomy-side FMN relative to contralateral (uninjured) control side nuclei. The ratios (with SEM) from the sham implant and the TP-treatment groups at $7 \mathrm{~d}$ postinjury are shown.

of tubulin mRNAs examined, in that $\beta_{\mathrm{II}}$-tubulin mRNA levels are selectively altered by the steroid, whereas, $\beta_{\mathrm{II}}{ }^{-}$or $\alpha_{1}$-tubulin mRNAs are not. Second, administration of testosterone results in a more rapid induction of $\beta_{\mathrm{II}}$-tubulin mRNA in axotomized neurons relative to that observed in axotomized motor neurons from non-hormone-treated animals. These findings support the hypothesis that the mechanism by which testosterone enhances the rate of axonal regeneration of facial motor neurons involves an augmentation of the neuronal cytoskeletal response pattern after axon severance and suggests steroidal alteration of the composition/physical properties of regenerating facial axons.

In a pioneering study done in 1976, Toran-Allerand demonstrated that gonadal steroids promote neurite outgrowth in hypothalamic and preoptic explant culture paradigms. The addition of exogenous estrogen or testosterone to the culture medium resulted in a proliferation of neuritic processes in both of these steroid-sensitive brain regions. Subsequent work in several in vivo models has shown that testosterone has very pronounced, reversible effects on dendritic length in spinal motoneurons of the bulbocavernosus muscle (Devoogd and Nottebohm, 1980; Kurz et al., 1986). Recently, Ferreira and Caceres (1991) have shown that gonadal steroids promote neurite outgrowth through the selective induction of microtubule-associated proteins, which increase the stability of microtubules. These findings are in agreement with our present data of differential regulation of tubulin gene expression in injured motoneurons by testosterone.

The accelerative effects of TP on axonal regeneration rates following facial nerve crush axotomy (Kujawa et al., 1991) are reminiscent of the regeneration stimulating effects obtained with the conditioning lesion (McQuarrie, 1983; Oblinger and Lasek, 1984). That is, prior axonal injury that "metabolically primes" the nerve cell body gives rise to accelerated regeneration rates in response to a subsequent lesion. It has been demonstrated in a number of studies that the rate of slow axonal transport changes in direct relationship to the metabolic status of the animal (Jakobson and Sidenius, 1980; McQuarrie et al., 1989). Accumulated evidence indicates that cytoskeletal and associated proteins are delivered to the axon via the slow component of axonal transport (reviewed in Brady and Lasek, 1982; Lasek et al., 1984). Importantly, the conditioning lesion paradigm, which results in accelerated axonal outgrowth rates, also selectively increases the transport rate of slow component b proteins (Maier and McQuarrie, 1990). It is possible that TP treatment, which augments cytoskeletal gene expression after axotomy, also increases the rate of delivery of essential proteins, like tubulin, to the growing tips of regenerating axons. We are currently testing this idea in the FMN lesion paradigm.

Five different $\alpha$-tubulin isotype mRNAs (Villasante et al., 1986) and five different $\beta$-tubulin isotype mRNAs, two of which $\left(\beta_{\mathrm{IVa}}\right.$ and $\beta_{\mathrm{IVb}}$ ) differ only in $3^{\prime}$ untranslated sequence (Sullivan, 1988), are expressed in mammalian brain. Axotomy itself is known to affect significantly the expression of $\beta_{\mathrm{II}^{-}}, \beta_{\mathrm{II}^{-}}$, and $\alpha_{1^{-}}$ tubulin mRNAs, but only marginally affect $\beta_{\mathrm{I}}$ and $\beta_{\mathrm{IV}}$-tubulin mRNA levels (Hoffman and Cleveland, 1988; Miller et al., 1989; Wong and Oblinger, 1990; Moskowitz et al., 1993). In the present study, we provide evidence for the further enhancement in the levels of only one of the three tubulin mRNAs examined by exogenous androgens in axotomized FMN. What is the significance of a selective change in expression of only some of the many tubulin genes for a neuron? The argument that unique properties are provided to the cytoskeleton by utilization of specific tubulin isotypes can be made. That such unique properties are endowed by the very small differences in the sequences of the various tubulin isotypes directly is perhaps unlikely. For example, all of the $\beta$-tubulin isotypes are highly homologous and differ only in sequences located at the very carboxyl end of the proteins (Lewis et al., 1985; Sullivan and Cleveland, 1986; Wang et al., 1986; Cleveland, 1987; Burgoyne et al., 1988; Sullivan, 1988). However, these carboxyl-terminal regions of tubulin are thought to be involved in binding of microtubuleassociated proteins (MAPs), and thus one way in which the small differences between the tubulin isotypes could be functionally very important is in enabling or preventing the interactions of certain tubulin isotypes with specific MAPs (Joshi and Cleveland, 1990). In turn, those interactions might affect microtubule assembly, stability, their spatial distribution, or perhaps their association with the motility mechanisms that move microtubules through axons in slow axonal transport. In this manner, selective regulation of the tubulin gene family by androgen after 

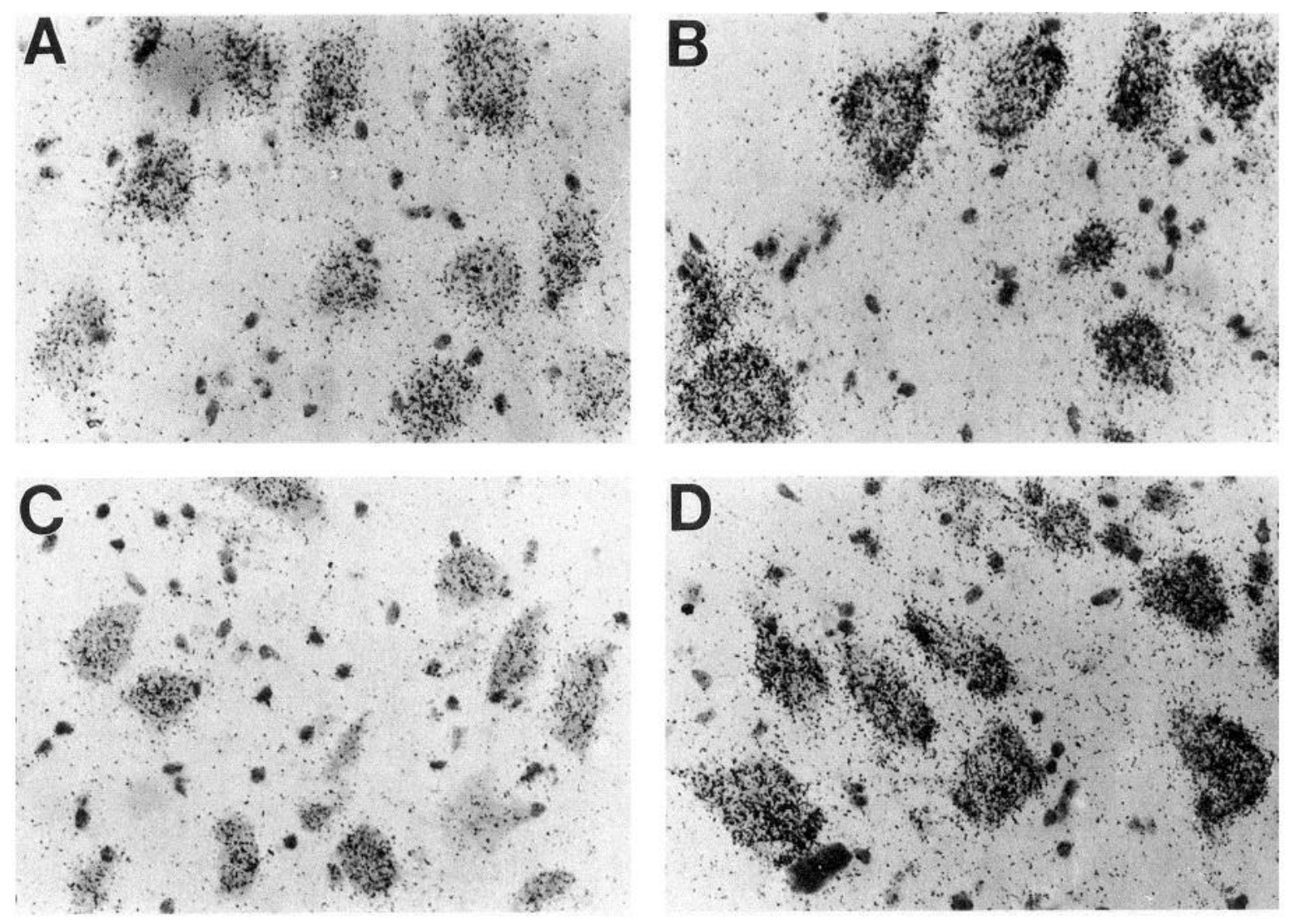

Figure 4. Emulsion autoradiograms of facial motor neurons after in situ hybridization with a ${ }^{35} \mathrm{~S}$-labeled $\beta_{\mathrm{n}}$-tubulin cDNA probe. Shown are examples of neurons from the following conditions: $A$, contralateral (uninjured) neurons in the FMN at $7 \mathrm{~d}$ postaxotomy with sham implant (no exogenous hormone); $B$, axotomized neurons $7 \mathrm{~d}$ after facial nerve transection and sham implant; $C$, contralateral (uninjured) neurons in the FMN from a TP-treated animal at $7 \mathrm{~d}$ post-axotomy; $D$, axotomized neurons from a TP-treated animal $7 \mathrm{~d}$ after facial nerve transection.

axotomy could exert a functional effect on the dynamics of newly growing axons.

The effects of androgen on the expression of mRNA of only a specific tubulin isotype in this study is of interest in light of the well-documented role of steroid hormones as transcription factors. Steroid hormones when complexed with receptors bind to regulatory elements in the genome and act as transcriptional enhancers for target genes (Yamamoto, 1985; Evans, 1988). The selective enhancement of expression of $\beta_{\mathrm{II}}$-tubulin in androgentreated, axotomized motor neurons suggests that the $\beta_{\mathrm{II}}$-tubulin gene contains steroid response elements that are responsible for modulating its expression. The augmentation of $\beta_{\mathrm{II}}$ mRNA levels from axotomized motoneurons in androgen-treated animals over the increase induced by axotomy alone may thus be mediated through transcriptional enhancement mechanisms. If in fact the $\beta_{\mathrm{II}}$-tubulin gene contains steroid response elements, the lack of significant effects of androgen on $\beta_{11}$-tubulin mRNA levels in uninjured FMN neurons in this study is somewhat surprising. It is apparent that a combination of androgen and axotomy is required to elicit the effects. Since the mechanisms that modulate tubulin mRNA levels after axotomy alone are not yet known, further study of the important molecular details of gene regulation in regenerating neurons is needed.

Recently, we have shown that TP enhances the response to injury by upregulating the nucleolar reaction that occurs after facial nerve severance, thereby, in essence, priming the nerve cell body for subsequent synthetic changes (Kinderman and Jones, 1993). By $6 \mathrm{hr}$ after facial nerve injury plus TP, the levels of ribosomal RNA within individual axotomized facial neurons increase approximately $39 \%$, relative to the unoperated side, whereas no changes in rRNA levels occur in injured neurons from non-hormone-treated animals until $1 \mathrm{~d}$ postoperative. These rRNA levels in the axotomized FMN in the presence of $\mathrm{TP}$ at $6 \mathrm{hr}$ approximate those observed in axotomized, nonhormone-treated neurons at $24 \mathrm{hr}$. Exposure to TP also increases the magnitude of change in rRNA levels after injury. Thus, it appears that the steroid shortens the time interval between axon disconnection and onset of the cell body reaction. Importantly, the effects of TP on cytoskeletal gene expression in injured neurons reported in this study mirror, temporally and in magnitude, the effects of the steroid on the ribosomal system. How TP accomplishes this at the molecular level is not known, although several potential explanations exist. First, the sequence of events that occur in injured neurons between the time of axon disconnection and axonal regeneration could be similar in hormone and nonhormone states, with the steroid simply temporally accelerating these events in a coordinated manner. Conversely, exposure to the hormone could result in a "bypassing" of several steps in the injury response and in some way trigger an accelerated rate of axonal regrowth through an alternate pathway.

The possibility that androgen treatment effects in this study are mediated indirectly must also be considered. For example, it is not improbable that steroid hormones induce the expression of neurotrophic factor receptors in target neurons. From this perspective, the cascade of effects of androgen administration in this study could be seen to be initiated with the induction of 
higher levels of a particular trophic factor receptor that in turn is capable of inducing expression of target genes after it complexes with its ligand. The trophic factors that are utilized by regenerating motoneurons are not completely characterized at this time but include ciliary neurotrophic and brain-derived ncurotrophic factors (Oppenheim et al., 1992; Sendtner et al., 1992; Yan et al., 1992). In the case of many of the neurotrophic factors, the responsive genes in neurons have yet not been entirely mapped. However, in the case of NGF, cytoskeletal genes such as tubulins and MAPs are well known to be targets of trophic factor stimulation (Drubin et al., 1985; Brugg and Matus, 1988). Thus, studies of this potential mechanism by which androgenic stimulation of FMN axonal growth rate is mediated would be of great interest. In order to address these issues and to establish causality in the role of TP in increasing the rate of facial nerve regeneration, it will be important in the future to determine the full extent of the actions of TP on the cytoskeletal response to injury and to determine the level(s) at which both the polymerase I system and the cytoskeletal genes are coordinately regulated.

\section{References}

Ausubel F, Kingston R, Brent R, Moore D, Seidman JG, Smith JA, Struhl K (1987) Current protocols in molecular biology. New York: Greene/Wiley.

Bond JF, Robinson GS, Farmer SR (1984) Differential expression of two neural cell-specific $\beta$-tubulin mRNAs during rat brain development. Mol Cell Biol 4:1313-1319.

Brady ST, Lasek RJ (1982) The slow components of axonal transport: movements, compositions and organization. In: Axoplasmic transport (Weiss DG, ed), pp 206-217. Berlin: Springer.

Brugg B, Matus A (1988) PC12 cells express juvenile microtubuleassociated proteins during nerve growth factor-induced neurite outgrowth. J Cell Biol 107:643-650.

Burgoyne RD, Cambray-Deakin M (1988) The cellular neurobiology of neuronal development: the cerebellar granule cell. Brain Res Rev 13:77-101.

Burgoyne RD, Cambray-Deakin MA, Lewis SA, Sarkar S, Cowan NJ (1988) Differential distribution of $\beta$-tubulin isotypes in cerebellum. EMBO J 7:2311-2319.

Cambray-Deakin M, Morgan A, Burgoyne RD (1987) Sequential appearance of cytoskeletal components during the early stages of neurite outgrowth from cerebellar cells in vitro. Dev Brain Res 37:197-207.

Chapin SJ, Bulinski JC. (1992) Microtubule stabilization by assemblypromoting microtubules-associated proteins: a repeat performance. Cell Motil Cytoskel 23:236-243.

Chomczynski P, Sacchi N (1987) Single-step method of RN $\Lambda$ isolation by acid guanidinium thiocyanate-phenol-chloroform extraction. Anal Biochem 162:156-159.

Cleveland DW (1987) The multitubulin hypothesis relisted: what have we learned? J Cell Biol 104:381-383.

Cohen RS, Pfaff DW (1981) Ultrastructure of neurons in the ventromedial nucleus of the hypothalamus in ovariectomized rats with or without estrogen treatment. Cell Tissue Res 217:451-470.

DeVoogd T, Nottebohm F (1981) Gonadal hormones induce dendritic growth in the adult avian brain. Science 214:202-204.

Drubin DG, Feinstein SC, Shooter EM MWK (1985) Nerve growth factor-induced neurite outgrowth in PC12 cells involves the coordinate induction of microtubule assembly and assembly-promoting factors. J Cell Biol 101:1799-1807.

Evans RM (1988) The steroid and thyroid hormone receptor superfamily. Science 240:889-895.

Faivre-Baumann A, Rosenbaum E, Puymirat J, Grouselle D, TixierVidal A (1981) Differential effects of steroids on fetal mouse hypothalamic cells in serum-free medium. Dev Neurosci 4:118-119.

Ferreira A, Caceres A (1991) Estrogen-enhanced neurite outgrowth: evidence for a selective induction of tau and stable microtubules. J Neurosci 11:392-400.

Goldstein LA, Kurz EM, Sengelaub DR (1990) Androgen regulation of dendritic growth and retraction in the development of a sexually dimorphic spinal nucleus. J Neurosci 10:935-946.
Gould E, Woolley CS, Frankfurt M, McEwen BS (1990) Gonadal steroids regulate dendritic spine density in hippocampal pyramidal cells in adulthood. J Neurosci 10:1286-1291.

Hoffman PN, Cleveland DW (1988) Neurofilament and tubulin gene expression recapitulated the developmental program during axonal regeneration. Induction of a specific b-tubulin isotype. Proc Natl Acad Sci USA 85:4530-4533.

Jakobson J, Sidenius P (1980) Decreased axonal transport of structural proteins in streptozotcin diabetic rats. J Clin Invest 66:292-297.

Jiang YQ, Oblinger MM (1992) Differential regulation of $\beta$ III and other tubulin genes during peripheral and central nervous system development. J Cell Sci 103:643-651.

Jones KJ, Evinger C (1991) Differential neuronal expression of $c$-fos proto-oncogene following peripheral nerve injury or chemically-induced seizure. J Neurosci Res 28:291-298.

Jones KJ, Pfaff DW, McEwen BS (1985) Early estrogen-induced nuclear changes in rat hypothalamic ventromedial neurons: an ultrastructural and morphometric analysis. J Comp Neurol 239:255-267.

Jones $\mathrm{KJ}$, Chikaraishi DM, Harrington CA, McEwen BS, Pfaff DW (1986a) In situ hybridization detection of estradiol-induced changes in ribosomal RNA levels in rat brain. Mol Brain Res 1:145-152.

Jones KJ, McEwen BS, Pfaff DW (1986b) Regional specificity in estradiol effects on ${ }^{3} \mathrm{H}$-uridine incorporation in rat brain. Mol Cell Endocrinol 45:57-63.

Jones KJ, Harrington CA, Chikaraishi DM, Pfaff DW (1990) Estradiol regulation of ribosomal RNA processing in rat ventromedial hypothalamic neurons: early detection by quantitative in situ hybridization. J Neurosci 10:1515-1521.

Joshi HC, Cleveland DW (1990) Diversity among tubulin subunits: toward what functional end? Cell Motil Cytoskel 16:159-163.

Kinderman NB, Jones KJ (1993) Testosterone enhancement of the nerve cell body response to injury: evidence using in situ hybridization and ribosomal DNA probes. J Neurosci 13:1523-1532.

Krey LC, McGinnis MY (1990) Time courses of the appearance/ disappearance of nuclear androgen + receptor complexes in the brain and adenohypophysis following testosterone administration/withdrawal to castrated male rats: relationships with gonadotropin secretion. J Stcroid Biochem 35:403-408.

Kujawa KA, Jones KJ (1990) Testosterone-induced acceleration of recovery from facial paralysis in male hamsters: temporal requirements of hormone exposure. Physiol Behav 48:765-768.

Kujawa KA, Kinderman NB, Jones KJ (1989) Testosterone-induced acceleration of recovery from facial paralysis following crush axotomy of the facial nerve in male hamsters. Exp Neurol 105:80-85.

Kujawa KA, Emeric E, Jones KJ (1991) Testosterone differentially regulates the regenerative properties of injured hamster facial motor neurons. J Neurosci 11:3898-3906.

Kujawa KA, Jacob JM, Jones KJ (1993) Testosterone regulation of the regenerative properties of injured rat sciatic motor neurons. $J$ Neurosci Res, in press.

Kurz EM, Sengelaub DR, Arnold AP (1986) Androgens regulate dendritic length of sexually dimorphic mammalian motoncurons in adulthood. Science 232:395-398.

Lasek RJ, Garner JA, Brady ST (1984) Axonal transport of the cytoplasmic matrix. J Cell Biol 99:212s-221s.

LaVelle A, LaVelle FW (1984) Neuronal reaction to injury during development. In: Early brain damage, neurobiology and behavior, Vol 12 (Almki CR, Finger S, eds). New York: Academic.

Lewis SA, Lee MG, Cowan NJ (1985) Five mouse tubulin isotypes and their regulated expression during development. J Cell Biol 101: 852-861.

Maier CE, McQuarrie IG (1990) Increased slow transport in axons of regenerating newt limbs after a nerve conditioning lesion. Dev Biol 140:172-181.

Matsumoto A, Micevych PE, Arnold AP (1988a) Androgen regulates synaptic input to motoneurons of the adult spinal cord. $J$ Neurose 8:4168-4176.

Matsumoto A, Arnold AP, Zampighi GA, Micevych PE (1988b) Androgenic regulation of gap junctions between motoneurons in the rat spinal cord. J Neurosci 8:4177-4183.

McQuarrie IG (1983) Role of the axonal cytoskeleton in the regenerating nervous system. In: Nerve, organ and tissue regeneration: research perspectives (Seil FJ, ed), pp 51-88. New York: Academic.

McQuarrie IG, Brady ST, Lasek RJ (1989) Retardation in the slow axonal transport of cytoskeletal elements during maturation and aging. Neurobiol Aging 10:359-365. 
Miller FD, Tetzlaff W, Bisby MA, Fawcett JW, Milner RJ (1989) Rapid induction of the major embryonic a-tubulin mRNA, Tal, during nerve regeneration in adult rats. J Neurosci 9:1452-1463.

Moskowitz PF, Smith R, Pickett J, Frankfurter A Oblinger MM (1993) Expression of the class III $\mathbf{b}$-tubulin gene during axonal regeneration of rat dorsal root ganglion neurons. J Neurosci Res 34:129-134.

Oblinger MM, Lasek RJ (1984) $\Lambda$ conditioning lesion of the peripheral axons of dorsal root ganglion cells accelerates regeneration of only their peripheral axons. J Neurosci 4:1736-1744.

Oblinger MM; Pickett J (1992) Rapid detection of neuronal mRNAs using 33P nucleotides for in situ hybridization. Du Pont Biotech Update 7(4): 172-173.

Oppenheim RW, Qin-Wei Y, Prevette D (1992) Brain-derived neurotrophic factor rescues developing avian motoneurons from cell death. Nature 360:755-757

Pearson RCA, Taylor N, Snyder SH (1988) Tubulin messenger RNA: in situ hybridization reveals bilateral increases in hypoglossal and facial nuclei following nerve transection. Brain Res 463:245-249.

Reisert I, Han V, Lieth E, Toran-Allerand D, Pilgrim C, Lauder J (1987) Sex steroids promote neurite outgrowth in mesencephalic tyrosine hydroxylase immunoreactive cells in vitro. Int J Dev Neurosci 5:9198.

Sendtner M, Holtmann B, Kolbeck R, Thoenen H, Barde Y-A (1992) Brain-derived neurotrophic factor prevents the death of motoneurons in newborn rats after nerve section. Nature 360:757-759.

Sullivan KF (1988) Structure and utilization of tubulin isotypes. Annu Rev Cell Biol 4:687-716.
Sullivan KF, Cleveland DW (1986) Identification of conserved isotype-defining variable region sequences for four vertebrate $\beta$-tubulin polypeptide classes. Proc Natl Acad Sci USA 83:4327-4331.

Tetzlaff W, Alexander SW, Miller FD, Bisby MA (1991) Response of facial and rubrospinal neurons to axotomy: changes in mRNA expression for cytoskeletal proteins and GAP-43. J Neurosci 11:25282544.

Toran-Allerand CD (1976) Sex steroids and the development of the newborn mouse hypothalamus and preoptic area in vitro: implications for sexual differentiation. Brain Res 106:407-412.

Vallee RB (1992) Molecular characterization of high molecular weight microtubule-associated proteins: some answers, many questions. Cell Motil Cytoskel 15:204-209.

Villasante A, Wang D, Dobner P, Dolph P, Lewis SA Cowan NJ (1986) Six mouse $x$-tubulin mRNAs encode five distinct isotypes: testisspecific expression of two sister genes. Mol Cell Biol 6:2409-2419.

Wang D, Villasante A, Lewis SA, Cowan NJ (1986) The mammalian $\beta$-tubulin repertoire: hematopoietic expression of a novel, heterologous b-tubulin isotype. J Cell Biol 103:1903-1910.

Wong J, Oblinger MM (1990) A comparison of peripheral and central axotomy effects on neurofilament and tubulin gene expression in rat dorsal root ganglion neurons. J Neurosci 10:2215-2222.

Yamamoto KR (1985) Steroid receptor regulated transcription of specific genes and gene networks. Annu Rev Genet 19:209-252.

Yan Q, Elliott J, Snider WD (1992) Brain-derived neurotrophic factor rescues spinal motor neurons from axotomy-induced cell death. $\mathrm{Na}$ ture 360:753-755. 